\title{
Papillary Squamo-Transitional Cell Carcinoma
}

\author{
Anusha M, Anuradha P, Praveen Kumar M and Lohith G* \\ Healthcare Global Enterprises limited, Bangalore, India
}

Submission:April 05, 2018; Published: May 07, 2018

${ }^{*}$ Correspondence Address: G Lohith, Consultant Radiation Oncologist, Chief Director-Radiomics and Radiogenomics, Healthcare Global Enterprises Limited, Bangalore, India, Email: lampard251185@gmail.com.

\section{Abstract}

Neoplasm of cervix continues to be major health burden in countries like India where screening tests are not widely followed or accessible. Squamous cell carcinoma is the most common histopathogy, constituting about $90 \%$ of all cervical carcinoma. Squamo-transitional carcinoma is a rare, poorly differentiated variant of Squamous cell carcinoma (SCC). It poses a therapeutic challenge considering rarity of disease and higher incidence of recurrence. Here, we present a premenopausal woman who was diagnosed with squamo-transitional carcinoma and treated at our institute.

\section{Introduction}

Malignancy of cervix continues to be major health burden worldwide and especially in countries with minimal access to screening tests. The average age at diagnosis is 45years. Squamous cell carcinoma is the common histopathologic type, accounting to nearly $90 \%$ of all carcinoma cervix cases. The most common variants of SCC are large cell keratinizing SCC, large cell nonkeratinizing SCC. Various less common variants of SCC have been described and include small cell SCC, papillary squamotransitional cell carcinoma (PSTCC), verrucous carcinoma, sarcomatoid squamous carcinoma.Papillary squamo-transitional cell carcinoma can be either well differentiated Papillary variant or poorly differentiated transitional cell variant (181 in devita). Koenig et al. [1] divided papillary squamo-transitional cell carcinoma into 3 groups - predominantly squamous (28.1\%), mixed squamous and transitional (50\%), and transitional (21.9\%). PSTCC are known to be aggressive with increased risk of locoregional recurrences and distant metastasis. They are usually treated like carcinoma cervix. Here we present clinical, pathological and radiological presentation, and treatment of 38 years old premenopausal woman with relevant literature.

\section{Case Report}

A 38year old, woman presented to us in June 2013 with complaints of white discharge per vaginum for past 6 months which was scanty associated with foul smell and mild pruritus. She also complained of post-coital bleeding per vagina for past 3 months. She gave no history of dyspareunia or inter-menstrual bleeding. She attained menarche at the age of 14years. She had 2 full term normal vaginal deliveries and was tubectomised after last childbirth. She gave no history of abortion or oral contraceptive pills usage. She was evaluated with Ultrasound abdomen and pelvis elsewhere which revealed bulky uterus with endocervical collection and Bilateral hydroureteronephrosis. The patient was referred to us for further management. She was moderately built and nourished without significant general physical or systemic findings. Per speculum examination revealed cauliflower-like (proliferative) growth replacing both the lips of cervix measuring about $5 \times 5 \mathrm{~cm}$ with infiltration of left parametrium up to the lateral pelvic wall. Punch biopsy of the lesion was taken which revealed features suggestive of Squamotransitional cell carcinoma. She was staged as per International federation of Gynecology and Obstetrics (FIGO) as Carcinoma cervix IIIB.

FDG PET CT Scan showed metabolically active lesion in cervix and left parametrium (SUV max 13.4) along with pelvic lymphadenopathy involving bilateral external iliac and right common iliac region (SUV $\max 12.2$ ) and retroperitoneal lymphadenopathy (SUV max 7.6). She was planned and treated with concurrent chemoradiation with IMRT Technique to a total dose of $56 \mathrm{~Gy} / 28$ \# to the Gross tumor volume and 50.4 Gy/28\# to the clinical target volume(including pelvic lymph nodal regions) over 41 days (26.06.13 to 07.08 .13 ). She received 5 cycles of concurrent weekly cisplatin. Interim PET CT scan showed Interval resolution of uterine cervix mass [2], near total interval resolution of bilateral external iliac and right common iliac lymphadenopathy. Interval resolution of retroperitoneal lymphadenopathy. There was solitary residual node in the right external iliac group. She underwent intra-cavitary brachytherapy to dose of $21 \mathrm{~Gy}$ in $3 \#$.

She received 3 cycles of adjuvant chemotherapy with 3 weekly Inj Paclitaxel and carboplatin (last on 29.11.13). She is on regular follow up since the completion of treatment. Pelvic examination revealed no disease and FDG PET CT Scan showed 


\section{Cancer Therapy \& Oncology International Journal}

no metabolically lesion. The patient is disease free for the past 5 years. ((Short of 3months)).

\section{Discussion}

Papillary squamo-transitional cell carcinoma is rare variant of squamous cell carcinoma which has higher propensity for delayed locoregional recurrences and distant metastases. It has been observed in previous studies that PSTCC is associated with HPV (human papilloma virus) infection through the detection of tumor suppressor protein, $\mathrm{p} 16$ [3-5]. The incidence of association with HPV infection is lower than that identified in SCC indicating probable another causative factor/s [6]. The review of literature shows that initially PSTCC was thought to be biologically like SCC depending upon the predominant histopathologic feature. Koenig et al studied 32 patients diagnosed with PSTCC [7]. They divided papillary squamo-transitional cell carcinoma into 3 groups depending upon predominant histologic featurepredominantly squamous (28.1\%), mixed squamous and transitional (50\%), and transitional (21.9\%).

Immunohistochemically, PSTCC are immune-reactive for CK7+/CK20-. In our patient, Immunohistochemistry was not done. Various treatment modalities being implemented over the years as per NCCN guidelines. Guidelines do not necessarily differ according to the histology [8]. Early lesions can be considered for surgical intervention alone - trachelectomy or hysterectomy with or without pelvic lymph node dissection, or upfront radiation therapy. Evaluation with MRI pelvis with contrast study is essential to identify cervical stromal invasion, extent of parametrial invasion and pelvic lymph nodal involvement. Trachelectomy places a significant role in those who present with HSIL findings on Pap smear. Trachelectomy provides adequate tissue to identify degree of stromal invasion and distinguish PSTCC from other histopathologic lesions. Locally advanced lesions should be considered for upfront definitive chemoradiation similar to SCC or adenocarcinoma of cervix followed by brachytherapy [9]. Radiation volumes usually include bilateral pelvic lymph nodal regions and primary cervical lesion with adequate margins. Concurrent weekly cisplatin acts as radiosensitizer. Brachytherapy provides more conformal pear-shaped dose distribution and increase total dose delivered to cervix and adjacent parametrium [10-13]. Long term followup with pelvic examination and imaging studies is required to detect recurrences at the earliest.

In our patient, staging FDG PET CT Scan revealed locally advanced cervical lesion with significant pelvic lymph nodal burden. She was treated with chemoradiation and adjuvant chemotherapy. Regular follow-up revealed that she is diseasefree for past 5years.

\section{Conclusion}

PSTCC is a very distinct histologic variant. Further studies are required to recognize to etiologic factors, prognostic factors, factors responsible for long term recurrence. Treatment approach remains same as SCC or adenocarcinoma of cervix. Need for long term follow-up to identify early recurrent lesions.

\section{References}

1. Koenig C, Turnicky R, Kankham C, Tavassoli F (1997) Papillary squamotransitional cell carcinoma of the cervix: a report of 32 cases. Am J Surg Pathol 21(8): 915-921.

2. Randell ME, Anderson WA, Mills SE, Kim JC (1986) Papillary squamous cell carcinoma of the uterine cervix: a clinicopathologic study of 9 cases. Int J Gynecol Pathol 5(1): 1-10.

3. Lininger R, Wistuba I, Gazdar A, Koenig K, Tavassoli F, et al. (1998) Human papillomavirus type 16 is detected in transitional cell carcinomas and squamotransitional cell carcinomas of the cervix and endometrium. Cancer 83(3): 521-527.

4. Fujimoto T, Sakuragi N, Schimizu M, Watari H, Takeda M, et al. (2002) Papillary squamous cell carcinoma of the uterine cervix: a report of two cases with human papillomavirus 16 DNA. Acta Obstet Gynecol Scand 81: 176-178.

5. Anand M, Deshmukh SD, Gulati HK (2013) Papillary squamotransitional cell carcinoma of the uterine cervix: A histomorphological and immunohistochemical study of nine cases. Indian J Med Paediatr Oncol 34(2): 66-71.

6. Turker LB, Gressel GM, Abadi M, Frimer M (2016) Papillary squamous cell of the cervix: Two cases and review of literature. Gynecologic oncology Reports 18: 18-21.

7. Nanda J Patil, Dhirajkumar B Shukla, Mamta Bharti, Mallika Mehta (2016) Papillary squamotransitional carcinoma of cervix: a series of four cases. Int J Reprod Contracept Obstet Gynecol 5(6): 1820-1822.

8. Michikazu Nagura, Masafumi Koshiyama, Noriomi Matsumura, Aki Kido, Tsukasa Baba, et al. (2014) Clinical approaches to treating papillary squamous cell carcinoma of the uterine cervix. BMC Cancer 14: 784 .

9. Akbar SA, Tunio MA, Al-Dandan S, Salamah KM, AlAsiri M (2016) Papillary Squamotransitional Cell Carcinoma of the Uterine Cervix: A Case Report and Review of the Literature. Case Rep Obstet Gynecol 2016: 7107910 .

10. Nagaraj TS, Kuladeepa Ananda Vaidya, Sukesh (2014) Papillary Squamous Cell Carcinoma of Cervix: A case report with review of literature. Int J Intg Med Sci Vol 1(1): 14-16.

11. Monika Anant, Amrita Singh, Vandita Y Singh (2017) Papillary Squamotransitional cell carcinoma cervix. A rare variant. Jaypee Journals, pp. 142-145.

12. Mohanvir Kaur (2017) Papillary Squamotransitional Cell Carcinoma Cervix- A Rare Case Report. Annals of International Medical and Dental Research 4(1): 15.

13. Wahal SP, Mohindroo S (2018) Two rare variants of cervical cancer with review of literature. Clin Cancer Investig J 3(3): 248-250. 
This work is licensed under Creative Commons Attribution 4.0 License DOI: $10.19080 /$ CTOIJ.2017.10.555792

\section{Your next submission with Juniper Publishers} will reach you the below assets

- Quality Editorial service

- Swift Peer Review

- Reprints availability

- E-prints Service

- Manuscript Podcast for convenient understanding

- Global attainment for your research

- Manuscript accessibility in different formats

( Pdf, E-pub, Full Text, Audio)

- Unceasing customer service

Track the below URL for one-step submission https://juniperpublishers.com/online-submission.php 